\title{
IMPACT OF IMPROVED TECHNOLOGIES ON PRODUCTIVITY AND PROFITABILITY OF RAPESEED- MUSTARD PRODUCTION AT FARM LEVEL IN WEST BENGAL, INDIA
}

\author{
A. Dutta* \\ Bidhan Chandra Krishi Viswavidyalaya, Mohanpur, Nadia-741252
}

\begin{abstract}
Ten year study of front line demonstrations (FLDs) on rapeseed-mustard was conducted to assess the potentiality of improvised production technology. In West Bengal, Rapeseed-mustard is the major oilseed crop contributing $53 \%$ of total oilseed production of the state. One of the major constraints is low productivity of this crop due to non adoption of recommended package of practices and situation-specific improved varieties by most of the growers. Data used for this study were pertained to FLDs in rapeseed-mustard conducted under 'Integrated Scheme on Oilseeds, Pulses, Oil palm and Maize (ISOPOM)' during 2005-06 to 2014-15. The study revealed $27 \%$ yield advantage by the adoption of improved varieties almost with other practices. The other components viz., adoption of right method and time of sowing, seed treatment, application of sulphur and boron, integrated fertilizer and irrigation management, integrated pest and disease management showed 37, 32, $26,32,26$ and $28 \%$ respectively yield advantage over farmers' practice. Popularization of these proven technologies to the rapeseed- mustard growers will help them to get higher economic returns with sustainable production system of the state.
\end{abstract}

Keywords: Economic potentials, FLD, improved technologies, rapeseedmustard

\section{INTRODUCTION}

India accounts for $12-15 \%$ of world's oilseed area, $7-8 \%$ of oilseeds output, 6$7 \%$ of vegetable oil production, $9-12 \%$ of vegetable oil import and $9-10 \%$ of vegetable oil consumption (Hegde, 2009). The country produces seven edible oilseed crops viz., groundnut, rapeseed-mustard, soybean, sunflower, sesame, safflower and niger and two non edible oilseeds viz., castor and linseed (Paroda, 2013). Despite having the largest area under oilseeds in the world (26.77 M ha), India currently

\footnotetext{
* Corresponding author email: amitavapors@gmail.com
} 
imports about $50 \%$ of total oil requirement (2011-12) at a huge cost of ₹56,000 crores (1 US\$ = ₹68) (Paroda, 2013). Though the diverse agro ecological conditions of West Bengal are also favourable for growing all these nine oilseeds, rapeseedmustard, groundnut, sesame and sunflower are the major oilseed crops grown in the state. Rapeseed-mustard solely contributes $53 \%$ of total oilseed production with productivity of $764 \mathrm{~kg} \mathrm{ha}^{-1}$ in the state during 2008-09 (Dutta, 2014). The productivity of rapeseed-mustard in the state is comparatively low. Realizing this situation, a ten year long demonstrations of improved rapeseed-mustard varieties along with improved production practices were conducted under ISOPOM during 2005-06 to 2014-15. This paper captures the productivity potentials and profitability of improved rapeseed mustard production technologies under real farm situations demonstrated through frontline demonstrations (FLDs) in West Bengal.

\section{MATERIALS AND METHODS}

The Technology Mission on Oilseeds (TMO) launched by Government of India in 1986 had a significant impact on overall oilseeds production of the country by raising it from 10.83 million tons in $1984-85$ to 24.35 million tons in 1996-97 (Venkattakumar et al., 2009). Thereafter there was a plateau in oilseed production when bulk amount was imported. To meet the huge demand of edible oils in the country, the Department of Agriculture and Cooperation (DAC) started implementing the Integrated Scheme on Oilseeds, Pulses, Oil palm and Maize (ISOPOM) mainly to benefit the small and marginal farmers as most of the oilseed area in the country is with this category of farmers. Under this scheme, FLDs are conducted every year by Pulses and Oilseeds Research Station, Berhampore, Murshidabad, West Bengal, under the close supervision of scientists for transfer of technology to minimize the yield gap through validation and demonstration of improved oilseed production technology under real farm situations (Dutta, 2011). These demonstrations included different component technologies, classified as non-monetary (viz., choice of improved varieties, improved cultivation method and optimum time of sowing), lowcost (viz., seed treatment, application of sulphur and boron), and cost effective (viz., integrated fertilizer and irrigation management, integrated disease management and integrated insect management) production technologies (Table 1). During the period from 2005-06 to 2014-15, 243 FLDs on rapeseed-mustard were carried out in rabi season in an average area of one acre per demonstration. The result showed that there was a wide yield gap between improved technology (IT) and farmers' practice (FP). In case of local check plots, existing practices being used by farmers followed were considered. In general the soils of the area were sandy loam with medium fertility status, medium in $\mathrm{K}_{2} \mathrm{O}$ and low in available $\mathrm{N}, \mathrm{P}_{2} \mathrm{O}_{5}$ and $\mathrm{C}$. The results of these demonstrations conducted at various locations over the years (Anon., 2005, 2006, 
2007, 2008, 2009, 2010, 2011, 2012, 2013 and 2014) have been summarized in the present paper based on data collected from FLD plots as well as the data on local practices commonly adopted by the farmers.

Table 1. Cultural Practices applied for improved technologies and farmer practices during 2005-06 to 2014-15

\begin{tabular}{|c|c|c|}
\hline Cultural Practices & Improved Technologies (IT) & Farmer Practices (FP) \\
\hline Varieties & Pitambari, NRCYS 05-02,Kalyan,JD-6 & Locally available varieties \\
\hline Time of sowing & Within October & $\begin{array}{l}\text { Very late. End of November to } \\
\text { December after harvest of Kharif } \\
\text { Paddy }\end{array}$ \\
\hline Method of Sowing & Line Sowing & Broadcasting \\
\hline \multirow[t]{3}{*}{$\begin{array}{l}\text { Fertilizer } \\
\text { Application }\end{array}$} & $\begin{array}{l}\text { Toria }\left(\mathrm{N}: \quad \mathrm{P}_{2} \mathrm{O}_{5}: \mathrm{K}_{2} \mathrm{O}\right) \quad @ \quad 80 \\
\mathrm{Kg} / \mathrm{ha}\end{array}$ & \multirow{3}{*}{$\begin{array}{l}\text { More } \mathrm{N} \text { (urea) application, less } \\
\mathrm{P}_{2} \mathrm{O}_{5} \text { and } \mathrm{K}_{2} \mathrm{O} \text { application without } \\
\text { maintaining balanced and } \\
\text { recommended dose. }\end{array}$} \\
\hline & $\begin{array}{l}\text { Yellow Sarson }\left(\mathrm{N}: \mathrm{P}_{2} \mathrm{O}_{5}: \mathrm{K}_{2} \mathrm{O}\right) @ 100 \\
: 50: 50 \mathrm{Kg} / \mathrm{ha}\end{array}$ & \\
\hline & $\begin{array}{l}\text { Mustard }\left(\mathrm{N}: \mathrm{P}_{2} \mathrm{O}_{5}: \mathrm{K}_{2} \mathrm{O}\right) @ 120: 60: 60 \\
\mathrm{Kg} / \mathrm{ha}\end{array}$ & \\
\hline Irrigation & $\begin{array}{l}\text { Toria -one } \\
\text { Yellow Sarson- one to two } \\
\text { Mustard - two to three }\end{array}$ & $\begin{array}{l}\text { one to two depending on } \\
\text { availability }\end{array}$ \\
\hline Plant Protection & $\begin{array}{l}\text { Seed treatment followed by spray of } \\
\text { fungicides and insecticides as per } \\
\text { schedule. }\end{array}$ & $\begin{array}{l}\text { No Seed treatment. } \\
\text { No spray of fungicides and } \\
\text { Insecticides at proper time. }\end{array}$ \\
\hline
\end{tabular}

\section{RESULTS AND DISCUSSION}

\section{Non-monetary production technologies}

Choice of varieties is a pre-requisite for getting higher production in any area. The popular variety B-9 (Benoy) in farmers practice showed very poor yield in several places due to cultivation of very old varieties, late sowing, infestation of diseases and insect. The yield increase due to improved varieties ranged from 14 to $47 \%$ with the mean value of $27 \%$ during $2005-06$ to $2014-15$. The improved variety Kalyan (WBBN-1) showed $47 \%$ yield advantage over local variety B-9 during 200607 (Appendix 1). The benefit cost ratios (BCR) due to improved varieties were 2.63 and 2.32 with IT and FP plots respectively. Overall, choice of improved varieties of rapeseed-mustard showed $₹ 5698 \mathrm{ha}^{-1}$ additional net returns than the local varieties (Table 2). Non adoption of row spacing leads to uneven population which might 
affect branching, siliqua plant ${ }^{-1}$ and seed setting leading to poor seed yield plant ${ }^{-1}$. The crop was broadcasted resulting poor yield and was sown mostly after harvest of aman rice when normal time of sowing was over. Besides this, rise of temperature during flowering and maturity period due to late sowing results; high incidence of insects and diseases and also force maturity of the crop, thereby reduces seed and oil yields. The (IT) of right time and method of sowing (Appendix 1) showed 35-39\% seed yield advantage with additional net returns of ₹ 7800-10,807 ha-1. BCR values of IT were 2.21-4.86 during the period (Appendix 1). Overall, the seed yield increased by using IT was $37 \%$ with additional net returns of ₹ 9207 ha $^{-1}$ (Table 2).

\section{Low-cost production technologies}

Adoption of seed treatment with chemicals showed 32\% yield advantage with additional net return of ₹ 7,275.00 ha ${ }^{-1}$ and BCR of 3.98 during 2006- 07 (Table 2 and Appendix 1). Application of sulphur and boron was essential for increasing the oil content and seed yield of mustard. Rapeseed mustard is very much sensitive to boron and its deficiency at flowering stage affect pollen viability and abortion of stamens and pistils resulting low seed yield (Dell and Lonbian, 1997). The demonstration during 2007-08 showed increased seed yield to the tune of $26 \%$ with additional net returns of ₹ 3,905 ha ${ }^{-1}$ with corresponding BCR of 2.31 (Table 2 and Appendix 1).

\section{Cost effective production technologies}

Demonstration of optimum dose of fertilizer and application method with appropriate time of irrigation was conducted in different years at various locations. The results revealed that the seed yield increment ranged from 15 to $60 \%$ and additional net returns were ranged from ₹ 3,680 to $16342 \mathrm{ha}^{-1}$ (Appendix 1). Overall, this IT gave $32 \%$ seed yield advantage with additional net returns of ₹ $8155 \mathrm{ha}^{-1}$ and BCR of 2.91 (Table 2). Tripathi et al. (2011) noted similar findings of high seed yield and benefit cost ratio under RDF.

Late sowing of rapeseed-mustard in farmers practice severely damaged by insects mainly by aphids. Proper plant protection measures increased seed yield by 6 $58 \%$ yield advantage with an additional net returns of ₹ $1265-14115 \mathrm{ha}^{-1}$. During the ten years period insect management registered $26 \%$ yield advantage with additional net returns of ₹ $5573 \mathrm{ha}^{-1}$ and BCR of 2.45 (Table 2 and Appendix 1). Among the rapeseed-mustard diseases alternaria blight was the major disease in West Bengal. Appropriate disease management practices demonstrated seed yield increase ranged from 11-55\% with additional net returns of ₹ 2033-12732 $\mathrm{ha}^{-1}$. Overall disease management practices increased seed yield to the tune of ₹ $6157 \mathrm{ha}^{-1}$ and BCR of 2.25 (Table 2 and Appendix 1). 
Table 2. Impact of FLDs on non-monetary, low-cost and cost-effective production technologies of rapeseed-mustard under real farm situations

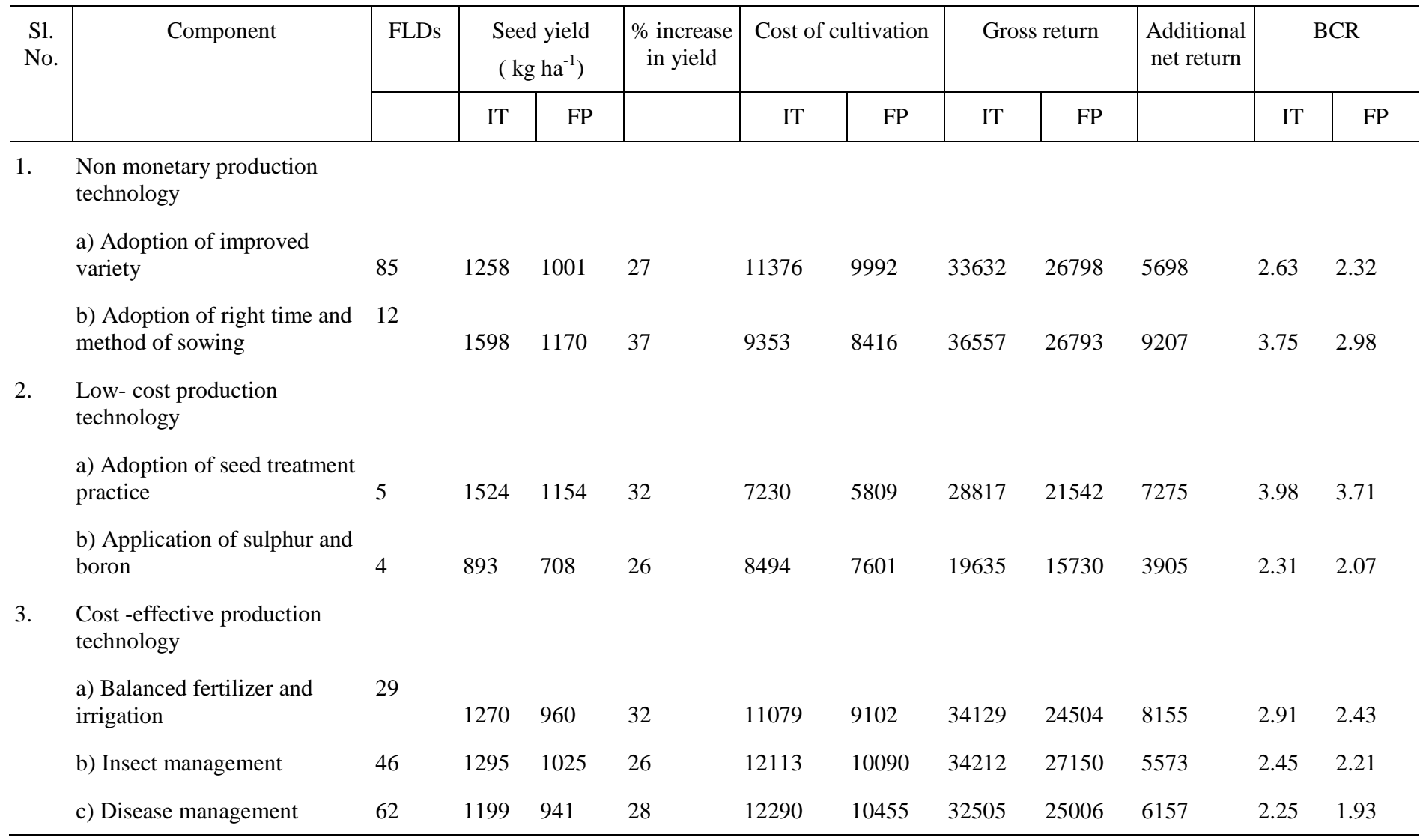

BCR: Benefit: Cost ratio; FP: Farmers' practice; IT: Improved technology; FLD: Frontline demonstration 
Appendix 1. Impact of improved rapeseed-mustard production technologies under real farm situations during 2005-06 to $2014-15$

\begin{tabular}{|c|c|c|c|c|c|c|c|c|c|c|c|c|}
\hline \multirow[b]{2}{*}{ Year } & \multirow[b]{2}{*}{ Component } & \multirow[b]{2}{*}{ FLDs } & \multicolumn{2}{|c|}{$\begin{array}{c}\text { Seed yield } \\
\left(\mathrm{kg} \mathrm{ha}^{1}\right)\end{array}$} & \multirow[t]{2}{*}{$\begin{array}{c}\% \text { increase } \\
\text { in yield }\end{array}$} & \multicolumn{2}{|c|}{$\begin{array}{l}\text { Cost of cultivation } \\
\text { (Tk/ha) } \\
\text { (₹) }\end{array}$} & \multicolumn{2}{|c|}{$\begin{array}{l}\text { Gross return } \\
\text { (Tk/ha) } \\
\text { (₹) }\end{array}$} & \multirow{2}{*}{\begin{tabular}{|c}
$\begin{array}{c}\text { Additional net } \\
\text { return } \\
(\mathrm{Tk} / \mathrm{ha}) \\
(₹)\end{array}$ \\
IT \\
\end{tabular}} & \multicolumn{2}{|c|}{$\mathrm{BCR}$} \\
\hline & & & IT & FP & & IT & FP & IT & FP & & IT & FP \\
\hline \multirow[t]{4}{*}{$2014-15$} & Improved variety & 5 & 1380 & 990 & 39 & 18673 & 14005 & 51750 & 37125 & 9957 & 1.77 & 1.65 \\
\hline & $\begin{array}{c}\text { Balanced fertilizer and } \\
\text { irrigation }\end{array}$ & 5 & 1635 & 1025 & 60 & 21738 & 15205 & 61312 & 38438 & 16342 & 1.82 & 1.53 \\
\hline & Insect management & 5 & 1563 & 990 & 58 & 21888 & 14530 & 58598 & 37125 & 14115 & 1.68 & 1.56 \\
\hline & Disease management & 5 & 1360 & 880 & 55 & 19573 & 14305 & 51000 & 33000 & 12732 & 1.61 & 1.31 \\
\hline \multirow[t]{3}{*}{ 2013-14 } & Improved variety & 10 & 1327 & 1111 & 20 & 18100 & 16900 & 46761 & 38909 & 6652 & 1.58 & 1.30 \\
\hline & Insect management & 5 & 1272 & 1198 & 6 & 17474 & 16900 & 38146 & 35940 & 1635 & 1.18 & 1.13 \\
\hline & Disease management & 5 & 1031 & 912 & 14 & 17171 & 16900 & 30492 & 27366 & 3305 & 0.8 & 0.62 \\
\hline \multirow[t]{4}{*}{ 2011-12 } & Improved variety & 8 & 985 & 846 & 17 & 13113 & 11518 & 29561 & 25365 & 2600 & 1.25 & 1.20 \\
\hline & $\begin{array}{c}\text { Balanced fertilizer and } \\
\text { irrigation }\end{array}$ & 7 & 1288 & 917 & 40 & 13808 & 11518 & 38630 & 27499 & 8841 & 1.80 & 1.39 \\
\hline & Insect management & 8 & 1094 & 888 & 23 & 13808 & 11518 & 32831 & 26636 & 3904 & 1.38 & 1.31 \\
\hline & Disease management & 17 & 1153 & 855 & 35 & 13808 & 11518 & 34604 & 25651 & 6663 & 1.51 & 1.23 \\
\hline \multirow[t]{3}{*}{$2010-11$} & Improved variety & 8 & 1425 & 1056 & 35 & 11942 & 9938 & 35625 & 26406 & 7215 & 1.98 & 1.66 \\
\hline & $\begin{array}{l}\text { Right time and method } \\
\text { of sowing }\end{array}$ & 4 & 1625 & 1198 & 36 & 12662 & 10990 & 40625 & 29938 & 9015 & 2.21 & 1.72 \\
\hline & Insect management & 4 & 1618 & 1088 & 49 & 13422 & 9990 & 40438 & 27188 & 9818 & 2.01 & 1.72 \\
\hline
\end{tabular}


A. Dutta

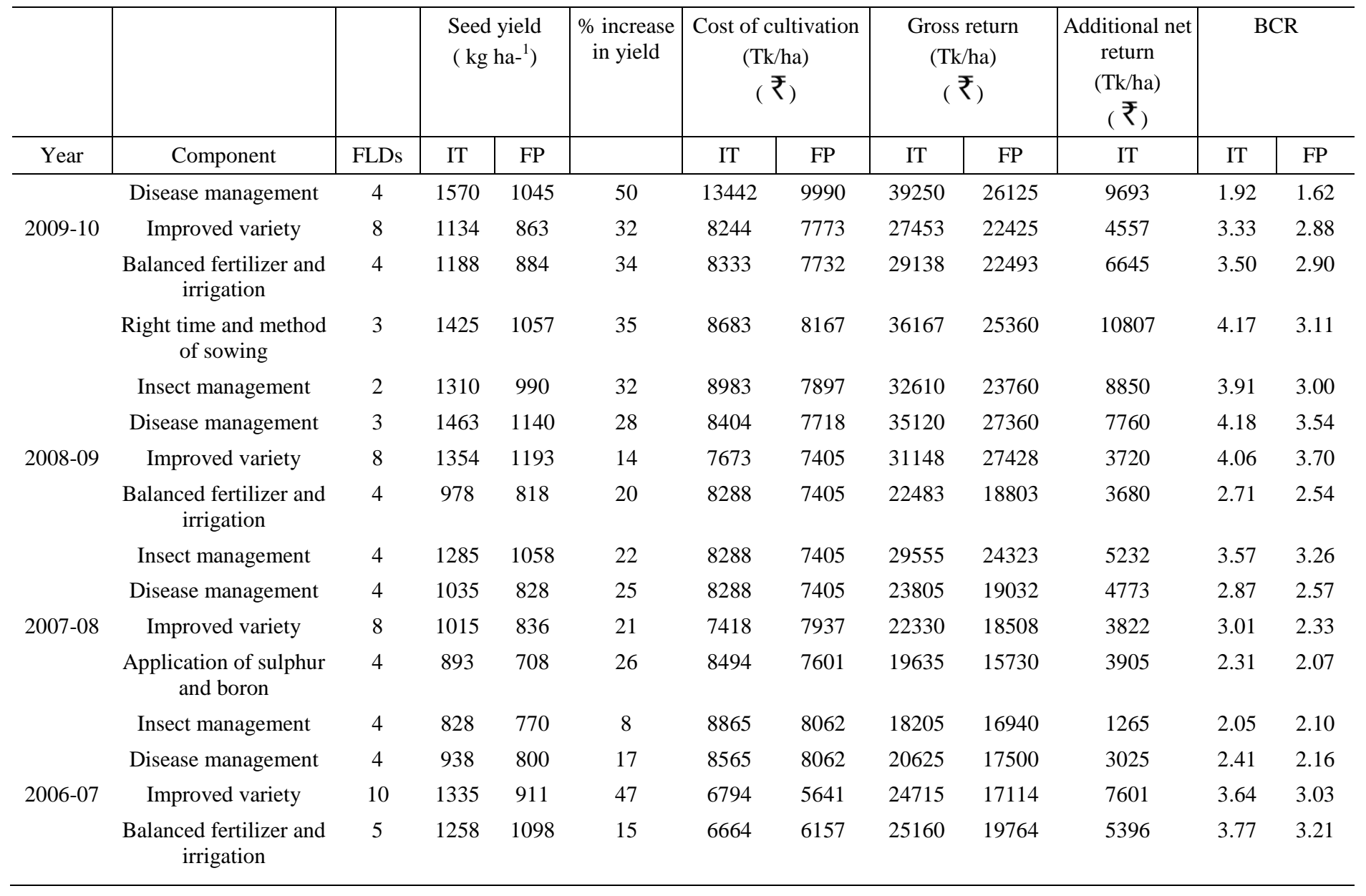


PERFORMANCE OF RAPESEED-MUSTARD UNDER IMPROVED FARMING PRACTICES 133

\begin{tabular}{|c|c|c|c|c|c|c|c|c|c|c|c|c|}
\hline \multirow[b]{2}{*}{ Year } & \multirow[b]{2}{*}{ Component } & \multirow[b]{2}{*}{ FLDs } & \multicolumn{2}{|c|}{$\begin{array}{c}\text { Seed yield } \\
\left(\mathrm{kg} \mathrm{ha}^{1}\right)\end{array}$} & \multirow[t]{2}{*}{$\begin{array}{c}\% \text { increase } \\
\text { in yield }\end{array}$} & \multicolumn{2}{|c|}{$\begin{array}{c}\text { Cost of cultivation } \\
\text { (Tk/ha) } \\
\text { (₹) }\end{array}$} & \multicolumn{2}{|c|}{$\begin{array}{l}\text { Gross return } \\
\text { (Tk/ha) } \\
\text { (₹) }\end{array}$} & \multirow{2}{*}{\begin{tabular}{|c}
$\begin{array}{c}\text { Additional net } \\
\text { return } \\
\text { (Tk/ha) } \\
\text { (₹ })\end{array}$ \\
IT \\
\end{tabular}} & \multicolumn{2}{|c|}{ BCR } \\
\hline & & & IT & FP & & IT & FP & IT & FP & & IT & FP \\
\hline \multirow{5}{*}{$2005-06$} & $\begin{array}{c}\text { Right time and method } \\
\text { of sowing }\end{array}$ & 5 & 1744 & 1254 & 39 & 6715 & 6092 & 32880 & 25080 & 7800 & 4.86 & 4.10 \\
\hline & Insect management & 5 & 1520 & 1206 & 26 & 7155 & 5601 & 29636 & 22401 & 7235 & 4.15 & 3.13 \\
\hline & Improved variety & 6 & 1447 & 1158 & 25 & 7553 & 5960 & 31620 & 24578 & 7042 & 4.18 & 4.12 \\
\hline & $\begin{array}{c}\text { Balanced fertilizer and } \\
\text { irrigation }\end{array}$ & 4 & 1273 & 1018 & 25 & 7640 & 6592 & 28050 & 20025 & 8025 & 3.87 & 3.03 \\
\hline & Insect management & 2 & 1425 & 1120 & 27 & 7160 & 6160 & 31150 & 29040 & 2110 & 3.35 & 3.70 \\
\hline
\end{tabular}

BCR: Benefit Cost ratio; FP: Farmers' practice; IT: Improved technology; FLD: Frontline demonstration 


\section{Impact of field level demonstrations (FLDs)}

Altogether 243 number of demonstrations were conducted during the period from 2005-06 to 2014-15 at the farmers field. Maximum seed yield was obtained by adoption of improved cultivation method and optimum time of sowing (1598 kg ha-1) followed by adoption of seed treatment practices $\left(1524 \mathrm{~kg} \mathrm{ha}^{-1}\right.$ ) (Figure 1). These two technologies involve no or minimum cost. The first component (nonmonetary technologies), adoption of improved varieties and adoption of improved cultivation method and optimum time of sowing showed 27 and 37\% seed yield advantage over farmers practice (FP) (Figure 2), respectively and therefore, farmers can adopt these two technologies without incurring any additional cost. The second component (lowcost production technologies), adoption of seed treatment practice and application of Sulphur and Boron showed 32 and 26\% seed yield advantage over FP, respectively, and hence, these two technologies would also be useful for them to have higher additional returns at minimum costs. The third component including all cost effective production technologies viz., integrated fertilizer and irrigation management, integrated insect and disease management showed 32, 26 and 28\% seed yield advantage, respectively (Figure 2). Hence judicious application of cost effective components is very much essential to get maximum additional net return.

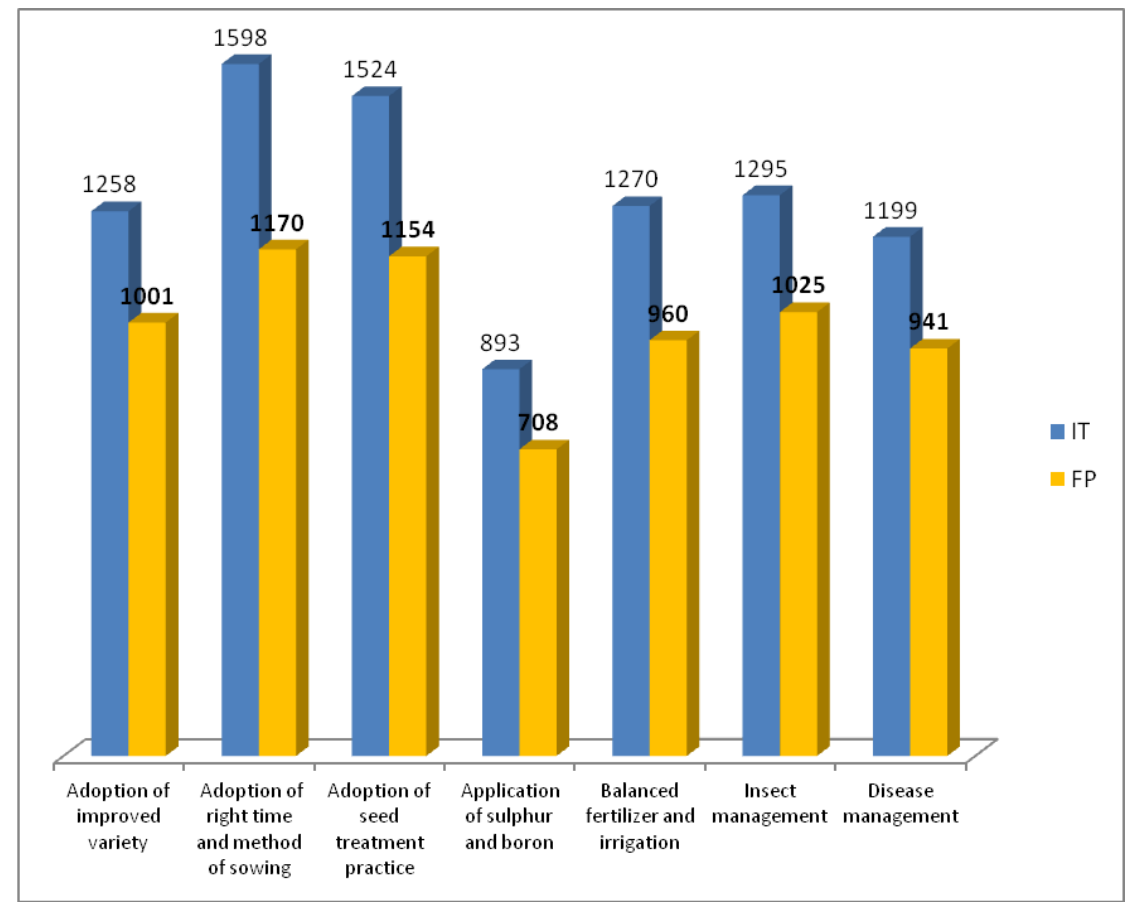

Figure 1. Comparison of seed yield $\left(\mathrm{kg} \mathrm{ha}^{-1}\right)$ under IT (Improved Technology) and FP (Farmers Practice) 


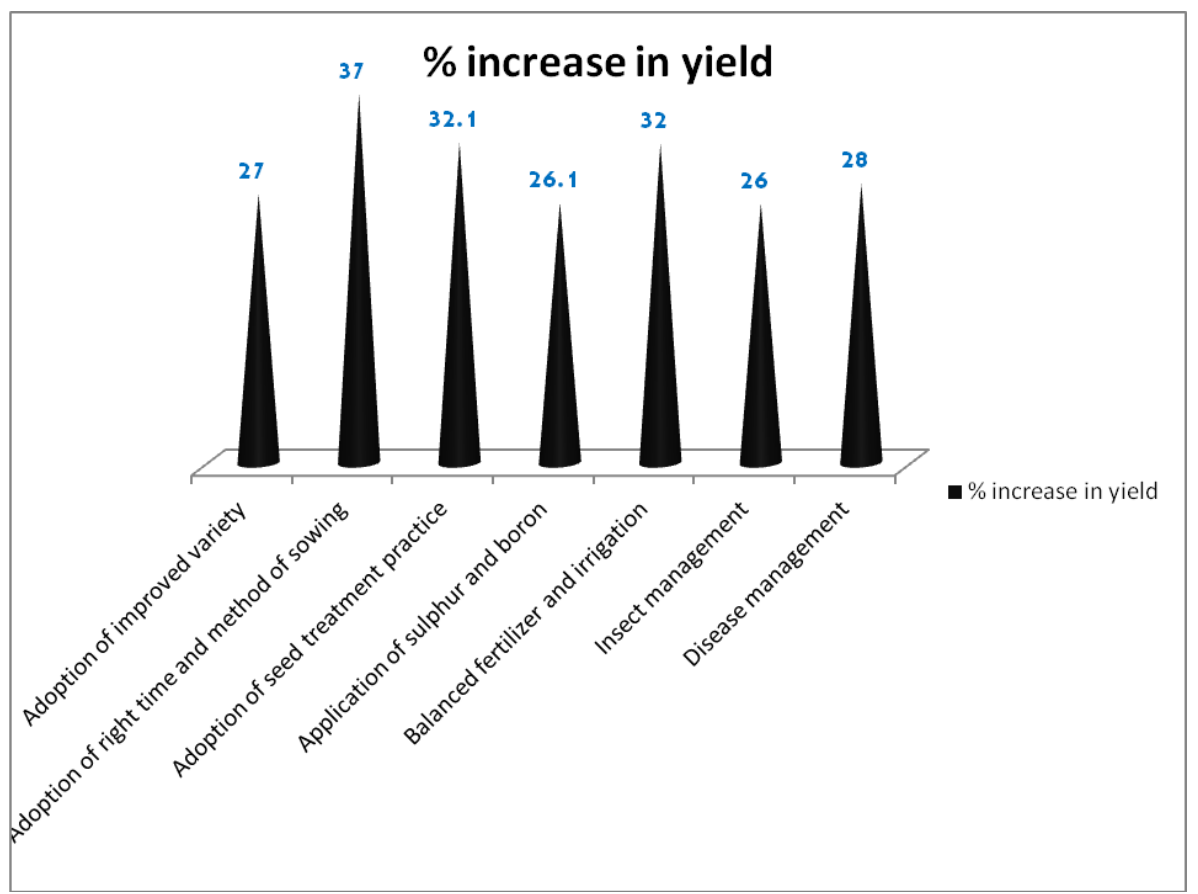

Figure 2. Percent increase of seed yield $\left(\mathrm{kg} \mathrm{ha}^{-1}\right)$ due to different components of improvised technology

\section{CONCLUSION}

The FLDs have shown the potential of improved technology (IT) to boost up the productivity significantly and increased the income of the farmers. Adoption of improved cultivation method and optimum time of sowing resulted maximum additional net return ( $₹ 9,207 \mathrm{ha}^{-1}$ ) followed by integrated fertilizer and irrigation management ( $₹ 8155 \mathrm{ha}^{-1}$ ) and adoption of seed treatment practice ( $₹ 7275 \mathrm{ha}^{-1}$ ). Popularization of these aforesaid ITs among the oilseed growers would help to get remunerative and sustainable yield with higher economic returns and finally enhance overall oilseed production without bringing more area under these crops in the country. The per capita consumption of vegetable oil is rising continuously. The country needs to produce at least $66.0 \mathrm{mt}$ of oilseeds by 2020 . Hence a concerted effort involving extension agencies, the State Department of Agriculture and research scientists should be directed to increase the knowledge and adoption by the farmers. Thus the adoption of improved technologies will boost up the oilseed production of the state as well as of the country. 


\section{REFERENCES}

Anonymous, 2005. Annual Report 2004-05. Pulses and Oilseeds Research Station, Berhampore, West Bengal. pp.238-39

Anonymous. 2006. Annual Report 2005-06. Pulses and Oilseeds Research Station, Berhampore, West Bengal. pp.245-46

Anonymous. 2007. Annual Report 2006-07. Pulses and Oilseeds Research Station, Berhampore, West Bengal. pp.156-57

Anonymous. 2008. Annual Report 2007-08. Pulses and Oilseeds Research Station, Berhampore, West Bengal. pp.146-48

Anonymous. 2009. Annual Report 2008-09. Pulses and Oilseeds Research Station, Berhampore, pp.168

Anonymous. 2010. Annual Report 2009-10. Pulses and Oilseeds Research Station, Berhampore, West Bengal. pp.147-48

Anonymous. 2011. Annual Report 2010-11. Pulses and Oilseeds Research Station, Berhampore, West Bengal. pp.151-152

Anonymous. 2012. Annual Report 2011-12. Pulses and Oilseeds Research Station, Berhampore, West Bengal. pp.162-65

Anonymous. 2013. Annual Report 2012-13. Pulses and Oilseeds Research Station, Berhampore, West Bengal. pp.157-63

Anonymous. 2014. Annual Report 2013-14. Pulses and Oilseeds Research Station, Berhampore, West Bengal. pp.163-66

Anonymous. 2015. Annual Report 2014-15. Pulses and Oilseeds Research Station, Berhampore, West Bengal. pp.163-65

Dell, B. and Lonbian, H. 1997. Physiological response of plants to low Boron. Plant and Soil, 193:103-120

Dutta, A. 2011. Impact of Front Line Demonstrations with different component Technologies on productivity potentials of Rapeseed-Mustard in West Bengal. SATSA MukhopatraAnnual Technical Issue, 15:101-105

Dutta, A. 2014. Impact of improvised production technology for rapeseed-mustard in West Bengal. Journal of Crop and Weed, 10(2):272-276

Hegde, D. M. 2009. Frontline demonstrations in oilseeds: Achievements and impact (200203 to 2006-07). Directorate of Oilseeds Research (ICAR), Rajendranagar, Hyderabad, India

Paroda, R. S. 2013. The Indian Oilseeds Scenario: Challenges and opportunities. Journal of Oilseeds Research, 30(2): 111-26

Tripathi, M. K., Chaturvedi, S., Shukla, D. K. and Saini, S. K.2011. Influence of integrated nutrient management on growth, yield and quality of Indian mustard (Brassica juncea L.) in terai region of north India. Journal of Crop and Weed, 7: 104-107

Venkattakumar, R., Ramanna, Rao., S. V., .Padmaiah, M. and Hegde, D. M. 2009. Productivity potentials and profitability of non-monetary, low-cost and cost-effective oilseeds production technologies. Journal of Oilseeds Research, 26: 140-4 